\title{
Anti Herpesviral Activity of Medicinal Plants Indicated to Treat Oral Diseases
}

\section{Carlos ED Igidio, Adriana S Santos, Dhierllate F Sousa, Bolívar 0 Landi and Aline 0 Conceição*}

Departamento de Ciências Biológicas, Universidade Estadual de Santa Cruz, Brazil

*Corresponding Author: Aline O Conceiçao, Departamento de Ciências Biológicas, Universidade Estadual de Santa Cruz, Brazil.
Received: January 27, 2021

Published: February 12, 2021

(C) All rights are reserved by Aline $\mathbf{0}$

Conceição., et al.

\begin{abstract}
Oral diseases constitute a serial public health problem. Periodontitis, one of the main oral diseases, has bacteria as the most prevalent agent, although today it is known that there are multiple factors that interfere with the installation and evolution of periodontics' disease. Herpesvirus infections, for example, lead to a drop in local immunity that can consequently lead to the multiplication of pathogenic bacteria and destructive periodontal disease. Within this problem, the importance of treatments of broad spectrum is stressed: bacteria, viruses, and the immune system. In this case, medicinal plants, recognized for their therapeutic action and the presence of a variety of metabolites are candidates for validation of their popular use. In this work we describe the in vitro anti herpesvirus study of four medicinal plants indicated to treat oral disease by a cocoa region community. Plants were collected in the field and ethanolic extracts were obtained from dried leaves of Schinus terebinthifolius (Anacardiaceae), Cajanus cajan (Fabaceae), and Tamarindus indica (Fabaceae). As a herpesvirus model, suid and equid herpesvirus were used. The best activity was seen for C. cajan against suid herpesvirus ( $96.84 \%$ of inhibition) at a concentration of $75 \mu \mathrm{g} / \mathrm{mL}$. However, the results presented here encourage further in vitro and in vivo tests in search of preventive or adjuvant therapies in the treatment of oral disease..
\end{abstract}

Keywords: Cytotoxicity; Antiviral; Periodontitis; Herpesviridae

\section{Introduction}

Periodontitis is an oral disease that affects a large proportion of the population worldwide [1]. Although it has been considered for many years as a bacterial disease, today periodontal disease is considered a multifactorial and multi-microbial inflammatory disease affecting periodontal tissues [2].

The maintenance of a stable periodontal environment depends on the balance between the presence of beneficial and pathogenic bacterial species and between protective or destructive immune responses $[3,4]$. Thus, the alteration of the microbiota balance is a crucial point in understanding the etiopathogeny of periodontal disease [5]. In addition, the presence of viruses plays a key role in this context and they are significantly associated with the implementation of bacterial periodontitis [6].

Herpesvirus infection, for example, may cause a drop in local immunity which can consequently lead to the multiplication of pathogenic bacteria and destructive periodontal disease [7]. Specifically, macrophages infected with viruses such as cytomegalovirus or Epstein-Barr have a reduced response to bacterial challenges [8]. In addition, herpesvirus proteins can serve as new adhesion sites for periodontopathic bacteria facilitating their adhesion and multiplication [9]. 
Within this problem, the importance of treatments with multiple performance spectrum (bacteria, viruses, and immune system) is highlighted. In this case, medicinal plants, recognized by their therapeutic action and the presence of a variety of metabolites, are strong candidates.

In this report the specific anti herpes viral in vitro action of three medicinal plants indicated for oral diseases by Southern Bahia - Brazil - community is described.

\section{Methodological procedures}

Botanical material

Schinus terebinthifolius Raddi (Anacardiaceae), Cajanus cajan (L.) Mills (Fabaceae), and Tamarindus indica L. (Fabaceae) leaves were collected from trees located in public areas of Una municipality (state of Bahia, Brazil) [lat: -15.299167 long: -39.045556 WGS84, $6 \mathrm{~m}]$, between April and September, 2017. Plant materials were identified and registered at Universidade Estadual de Santa Cruz herbarium under voucher number HUESC-23.560; HUESC-23.605, HUESC-23.582, respectively.

Leaves were washed, dried, and powdered. The extract of each plant was obtained by decoction and submitted to lyophilization. For use in cytotoxicity and antiviral tests, lyophilized extracts were weighed, diluted in minimal essential medium (Gibco® by Life Technologies) and filtered in sterile membranes with pores of 0.22 $\mu \mathrm{m}$ Biofil@. A $10 \mathrm{mg} / \mathrm{mL}$ concentration of extracts were distributed in sterile polypropylene microtubes and stored at $4^{\circ} \mathrm{C}$ until use.

\section{Cytotoxic and antiviral assay}

The cytotoxic and antiviral essays were done using the Vero cell line (ATCC-CCL81) and followed the technique described by Silva et al. [10]. For that, cells were maintained in minimal essential medium (MEM) supplemented by $10 \%$ bovine fetal serum. To perform both cytotoxic and antiviral tests, cells were seeded in 96 well plates 24 hours before tests. Cytotoxicity was evaluated by minimal non-cytotoxic concentration, (MNCC) method through cell integrity visualisation. Extracts were solubilized at concentrations ranging from 12.5 to $500 \mu \mathrm{g} / \mathrm{mL}$. MEM and dimethylsulfoxide (DMSO) $2 \%$ were used as control. The final cell visualization was performed after $48 \mathrm{~h}$ incubation time.
The antiviral activity against type 1 suid (SuHV- 1; Nova Prata strain) and equid (EHV-1; A4/72 strain) herpesvirus was determined by he viral Median Tissue Culture Infectious Dose $\left(\mathrm{TCID}_{50}\right)$ was identified and values were obtained by comparing non-treated infected cells and treated infected cells TCID $_{50}$ [11]. Results were expressed as viral inhibition index (VII) [12]. Also the inhibition percentage (IP) was calculated using the anti-logarithmic TCID50: $\mathrm{PI}=(1-\operatorname{antilog} \mathrm{T} / \operatorname{antilog} \mathrm{C}) \times 100$ where $\mathrm{T}$ corresponds to the virus titer of the extract treated cells and $C$ is the viral titer of the untreated cells [13].

\section{Results, Discussion and Conclusion}

In the medicinal plants field, there is still a great distance between the biological potential revealed in the popular culture and the proof of the declared biological potential or existing potentials in the substances present in these plants. The study of therapeutic and pharmacological properties is still scarce, especially with regard to their cytotoxicity profile [14] and knowledge of the effect of plant extracts on human and animal cells, has been the starting point in pharmacognosy research [15].

In the present study, the antiviral activity of the three medicinal plants indicated to treat oral diseases in the Southern Bahia, Brazil community showed distinguished anti herpesviral action against suid herpesviral at in vitro suitable extract concentration. Furthermore, the results of the Cajanus cajan leaves aqueous extract antiviral activity are outlined in Table 1.

In the Southern region of the state of Bahia, Tamarindus indica leaves tea was reported as having traditional usage on toothache treatment $[16,17]$. In addition, the tamarind ingestion in the diet can regulate fluoride, copper, and calcium clearance [18]. Thus, it is suggested here to deepen the chemical and biological studies of this plant.

As well as T. indica, Cajanus cajan was also reported in the treatment of toothache by the population of the Cachoeira River [16] and Una community [17] in the Southern of Bahia; besides, C. cajan is a Brazilian plant cited in the literature due to its use in primary health care against allergic disorders and gastritis [19]. 


\begin{tabular}{|l|c|c|c|c|c|}
\hline \multirow{2}{*}{ Family } & Plant species & Popular name & MNCC & \multicolumn{2}{|c|}{ VII (PI) } \\
\cline { 4 - 6 } & & & $\mathbf{\mu g} / \mathbf{m L})$ & EHV & SuHV \\
\hline Anacardiaceae & Schinus terebinthifolius & Pepper tree & 50 & $0.74(81.80 \%)$ & $0.74(81.80 \%)$ \\
\hline Fabaceae & Cajanus cajan & Andu & 75 & NI & $1.5(96.84 \%)$ \\
\hline Fabaceae & Tamarindus indica & Tamarind & 25 & NI & $1(90 \%)$ \\
\hline
\end{tabular}

Table 1: Antiviral activity of medicinal plants indicated to treat oral diseases by Southern Bahia, Brazil, community. MNCC: Minimal Non Cytotoxic Concentration; NI: No Inhibition; EHV: Equid Herpesvirus; SuHV - Suid Herpesvirus

Schinus terebinthifolius Raddi, the third plant cited by communities of Southern Bahia, showed a less prominent in vitro anti herpesvirus activity when compared with the other two plants tested. Interestingly, although frequently cited by communities, in vitro [20] and in vivo [21] show only mild activity as it was found for antiviral potential. For this plant it would be interesting to continue the evaluation of its potential in the treatment of oral diseases with higher doses in view of two aspects: 1) the acute and subacute oral administration of the dried extract of other part of Schinus terebinthifolius did not produced toxic effects in Wistar rats [22], and 2) using the $\mathrm{IC}_{50}$ method with the present aqueous extract we obtained non-toxic concentrations of $125 \mu \mathrm{g} / \mathrm{mL}$ (unpublished data).

In addition, there are two important aspects in the interference of plants in viral infection: preventive and coadjuvant. The ethanolic extract of Melissa officinalis [23] and Terminalia chebula [24], for example, acting on the adhesion and penetration of resistant and acyclovir-sensitive HSV can prevent clinical infection or the administration of nucleoside analogues supplemented with natural products may be an effective strategy in the treatment of lytic or latent herpetic infection [25].

Thus, in view of the results obtained here, the importance in the continuity of in vivo studies and in a context of broad microbial spectrum is highlighted.

\section{Bibliography}

1. Petersen PE and Ogawa H. "The global burden of periodontal disease: towards integration with chronic disease prevention and control". Periodontology 200060 (2012): 15-39.

2. Arweiler NB and Netuschil L. "The Oral Microbiota". Advances in Experimental Medicine and Biology 902 (2016): 45-60.
3. Berezow AB and Darveau RP. "Microbial shift and periodontitis". Periodontology 200055 (2011): 36-47.

4. Darveau RP. "Periodontitis: a polymicrobial disruption of host homeostasis". Nature Reviews in Microbiology 8 (2010): 481490.

5. Contreras A., et al. "Periodontal microbiology in Latin America”. Periodontology 200067 (2015): 58-86.

6. Saygun I., et al. "Quantitative analysis of association between herpesviruses and bacterial pathogens in periodontitis". Journal Periodontal Research 43 (2008): 352-359.

7. Slots J. "Herpesviral-bacterial interactions in periodontal diseases". Periodontology 200052 (2010): 117-140.

8. Lin YL and Li M. "Human cytomegalovirus and Epstein-Barr virus inhibit oral bacteria-induced macrophage activation and phagocytosis". Oral Microbiology and Immunology 24 (2009): 243- 248.

9. Teughels W., et al. "Human cytomegalovirus enhances A. actinomycetemcomitans adherence to cells". Journal of Dentistry Research 86 (2007): 175-180.

10. Silva LD., et al. "Phytochemical, cytotoxicity, and antiherpesviral comparison between three Lantana species". Asian Journal of Science and Technology 9.10 (2018): 8722- 8726.

11. Kaziyama VM., et al. "Atividade antiviral de extratos de plantas medicinais disponíveis comercialmente frente aos herpesvírus suíno e bovino". Revista Brasileira de Plantas Medicinais 14 (2012): 522-528. 
12. Koseki I., et al. "Antiviral activity of plant extracts against aphthovirus, pseudorabies virus and pestivirus in cell cultures". Microbios Letters 44 (1990): 19-30.

13. Nishimura T., et al. "Antiviral compounds. XII. Antiviral activity of amidinohydrazones of alkoxyphenyl-substituted carbonyl compounds against influenza virus in eggs and in mice". Kitasato Archives of Experimental Medicine 50 (1977): 39-46.

14. Desoti VC., et al. "Triagem fitoquímica e avaliação das atividades antimicrobiana e citotóxica de plantas medicinais nativas da região oeste do estado do Paraná". Arquivos de Ciências da Saúde UNIPAR, Umuarama 15.1 (2011): 3-13.

15. Rates S. "Promoção do uso racional de fitoterápicos: uma abordagem no ensino de Farmacognosia". Revista Brasileira de Farmacognosia 11.2 (2001): 57-69.

16. Moreira R., et al. "Abordagem Etnobotânica acerca do Uso de Plantas Medicinais na Vila Cachoeira, Ilhéus, Bahia, Brasil". Acta Farmaceutica Bonaerense 21.3 (2002): 205-211.

17. Landi, BO. "Levantamento etnobotânico e atividade antibacteriana in vitro de plantas utilizadas no tratamento de infecções bucais em área de Mata Atlântica no município de Una, Bahia. Ilhéus, BA" Master Thesis. Universidade Estadual de Santa Cruz. Programa de Pós-graduação em Ciências da Saúde (2017).

18. Khandare A., et al. "Effect of tamarind ingestion on fluoride excretion in humans". European Journal of Clinical Nutrition 56 (2002): 82-85.

19. Khandare AL., et al. "Additional beneficial effect of tamarind ingestion over defluoridated water supply to adolescent boys in a fluorotic area". Nutrition 20.5 (2004): 433-436.

20. Fenner R. "Plantas utilizadas na medicina popular brasileira com potencial atividade antifúngica". Brazilian Journal of Pharmaceutical Sciences 42.3 (2006).

21. Leite SR., et al. "Randomized clinical trial comparing the efficacy of the vaginal use of metronidazole with a Brazilian pepper tree (Schinus) extract for the treatment of bacterial vaginosis". Brazilian Journal of Medical and Biological Research 44.3 (2011): 245-252.
22. Lima LB., et al. "Acute and subacute toxicity of Schinus terebinthifolius bark extract". Journal of Ethnopharmacology 126.3 (2009): 468-473.

23. Astani A., et al. "Attachment and Penetration of Acyclovirresistant Herpes Simplex Virus are Inhibited by Melissa officinalis Extract". Phytotherapy Research 28 (2014): 1547-1552.

24. Kesharwani A., et al. "Anti-HSV-2 activity of Terminalia chebula Retz extract and its constituents, chebulagic and chebulinic acids". BMC Complementary and Alternative Medicine 17 (2017): 110.

25. Son M., et al. "Bioactive Activities of Natural Products against Herpesvirus Infection". Journal of Microbiology 51.5 (2013): 545-551.

\section{Assets from publication with us}

- Prompt Acknowledgement after receiving the article

- Thorough Double blinded peer review

- Rapid Publication

- Issue of Publication Certificate

- High visibility of your Published work

Website: www.actascientific.com/

Submit Article: www.actascientific.com/submission.php Email us: editor@actascientific.com

Contact us: +919182824667 